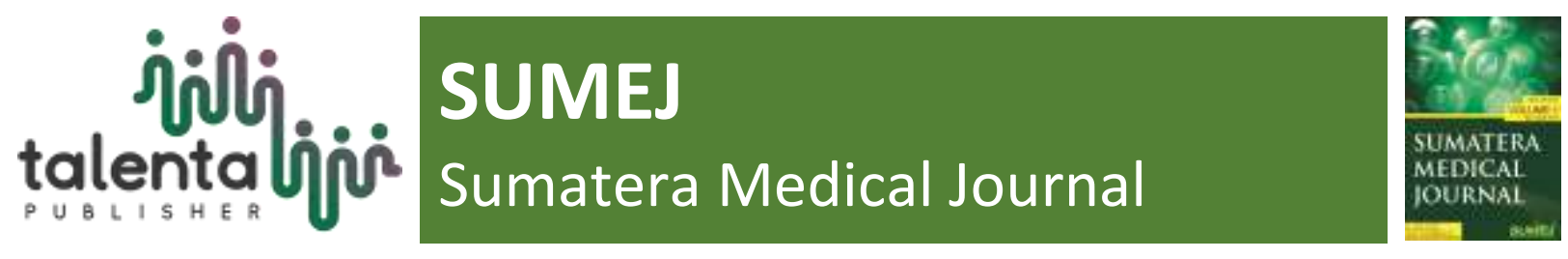

\title{
Factors Influencing the Decision of Parents to LP in Pediatric with CNS Infection
}

\section{D.D. Antarini, Y. Dimyati, N. Rosdiana, I.I. Fujiati, and C.P. Destariani}

Departments of Child Health Medical School, Faculty of Medicine Universitas Sumatera Utara, Medan, North Sumatera, Indonesia

\begin{abstract}
Lumbal Puncture (LP) is a procedure that can help to diagnosed CNS infection in children. The procedure of LP is a common invasive procedure, but sometimes it had refused by the parents. Furthermore, it can cause a delayed in the diagnosis and affected the prognosis. The subject was the parents of pediatric patients with CNS infection. We have a questionnaire and using Chi-square and Fisher exact test to analyze factors that influenced the parent's decision of LP procedure. From the parents of 50 children with CNS infection, 19 parents (38\%) were refused the LP procedure. Father's education was related to the refusal of LP procedure with PR 6.64 (95\%CI; 8.95-788.08). Mother's education was related to the refusal of LP procedure with PR 7.69 (95\%CI; 3.19-16.24). There was the significant result of the parent's education with the decision of LP procedure.
\end{abstract}

Keyword: Children, Factors of Refusal, Lumbar Puncture

Received 28 Aug 2019 | Revised 12 Sep 2019 | Accepted 17 Sep 2019

*Corresponding author at: Departments of Child Health Medical School, Faculty of Medicine 


\section{Introduction}

Central Nervous System (CNS) infection is differ-ent from other infections. It is known as the most dangerous disease which can develop rapidly and cause severe damage or even death if it is managed as early as possible. The etiology of this infection is the virus, bacteria, or other microorganisms (Pokorn, 2003).

Clinical manifestation of CNS infection is decreased consciousness, headache, the symptom of increasing intracranial pressure (e.g., vomiting, cardi-ovascular disorder, and respiratory disorder), seizure, and vocal symptom from CNS infection (Pokorn, 2003; Doherty, 2014).

The World Health Organization (WHO) estimates that 426,000 children suffered meningitis and 85.000 of them result in mortality. The incidence rate ranks from 9th to 10th of the disease pattern in the Education Hospitals in Indonesia. The incidence rate of meningitis in Indonesia is around 158/100,000 per year. In the year 2011 until 2014, RSUP Haji Adam Malik reported that 157 children who suffered from CNS infection were treated in the hospital. CNS in-fection especially meningitis is a serious problem which needs the efficient method to diagnose. Phys-ical examination is not enough in diagnosing menin-gitis accurately, but also need to analyze cerebrospi-nal fluid (CSF) which is obtained by lumbar puncture. Lumbar puncture is a gold standard recommended by IDAI (Ikatan Dokter Anak Indonesia) to diagnose intracranial infection (Kneen R, 2016; Ellenby MS, 2006).

Lumbar puncture (LP) is an important indication to diagnose and treat. However, lumbar puncture of-ten causes anxiety and stress in patients and their families, so many parents refuse this procedure. Par-ents' decision is influenced by their perception of whether lumbar puncture is important or not, the possibility of complication, waiting for family's de-cision, looking for other alternatives, and considering that without lumbar puncture patient will recover by itself. Research conducted in the United Arab Emir-ates in 2013 revealed that the difference in percep-tion, confidence, and over-compliant with parents' decision could give indications for developing the accurate strategy for approval of lumbar puncture (Ellenby, 2006; Narchy, 2013). This is the background of this study for finding out factors which influence parents' refusal against lumbar puncture.

\section{Methodology}

This study used the observational method with the cross-sectional design which assessed some factors that influenced parent decision on lumbar puncture in the Pediatric Unit of Haji Adam Malik Hospital, Medan. This study was conducted from March to May 2016. There were 50 samples that comprised of the newborn until 18 years old children who had clinical symptoms of seizure and the decrease in con-sciousness who were treated in Haji Adam Malik Hospital, Medan. Subjects were gathered by inter-views with parents or guardians by using question-naire 
on personal data, parent's data, history of pre-vious illness, and history of previous medications, parent's education, parent's understanding of lumbar puncture, and the reasons for parent's decision. This study had been unapproved by Research Ethics Committee of Faculty of Medicine, Universitas Su-matera Utara. The data were gathered, processed, and analyzed by using computer program at the sig-nificance level of $\mathrm{p}$-value $<0.05$. Bivariate analysis was used to assess factors which influenced parents' decision toward lumbar puncture on their children. Chi-square test and Fisher's exact test were used for the statistic test if the test requirements were ful-filled.

\section{Result}

This study was conducted at Haji Adam Malik Hospital, Medan, from March until May 2016. This study included parents of 50 children who suffered from central nervous system infection, which consist of 30 boys and 20 girls. In this study, the average age of the children was 4.04 \pm 2.97 years. The characteristics of samples can be seen in Table 4.1.

Table 4.1 Demography Characteristic of Sample

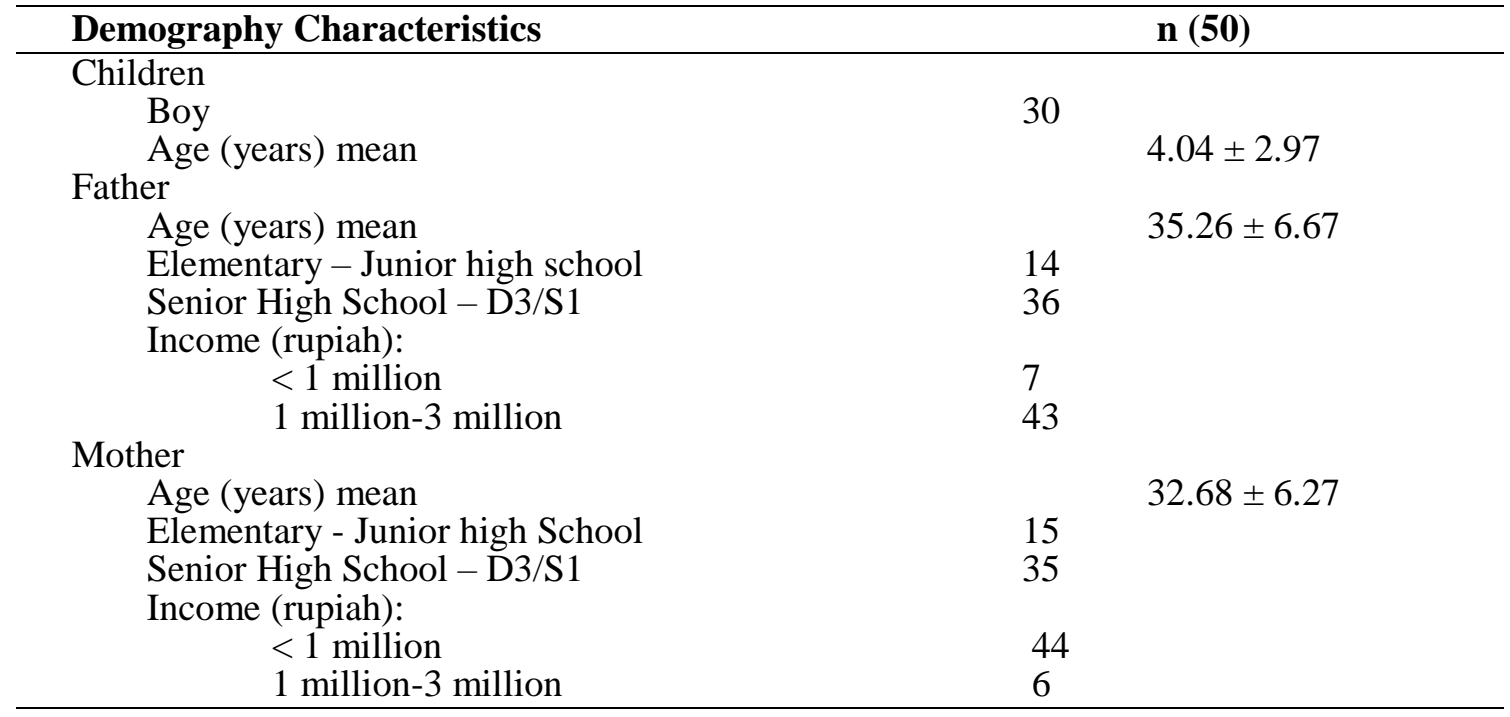

Father education was related to the refusal of LP procedure with PR 6.64 (95\%CI; 8.95-78.08, p $<0.05$ ). Mother education was related to the refusal of LP procedure with PR 7.69 (95\%CI; 3.19$16.24, \mathrm{p}<0.05)$.

Table 4.2 Relationship Between Parent's Decision Parents' Decision Education

$\begin{array}{llll}\text { Decision } & \text { PR } & \mathbf{P} & \mathbf{9 5 \%}\end{array}$

Refusal Obtained

\section{Father Education}

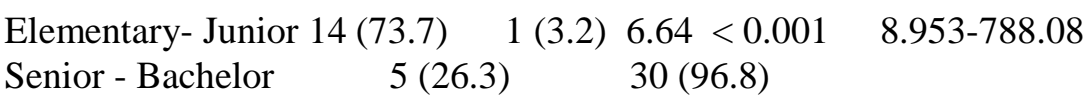

Mother Education

Elementary- Junior

Senior - Bachelor 
The assessment of parents' knowledge and attitude toward the action of LP was based on their understanding, benefit, complication, and information toward the action. Parents' knowledge of LP correlated with their refusal against Lumbal puncture PR 2.66 (95\% CI $0.821-0.78, \mathrm{p}<0.05$ ). The complication of LP correlated with the refusal PR 3.1 (95\% CI $2.02-4.64, \mathrm{p}<0.05$ ). The correlation can be seen in Table 4.3

Table 4.3 Relationship between parents decision and knowledge

\begin{tabular}{|c|c|c|c|c|c|c|c|c|}
\hline & \multicolumn{4}{|c|}{ Decision } & \multirow{2}{*}{\multicolumn{2}{|c|}{$\mathbf{P R}$}} & \multirow[t]{2}{*}{$\mathbf{P}$} & \multirow[t]{2}{*}{$95 \% \mathrm{CI}$} \\
\hline & & Refusal & Obtai & ned & & & & \\
\hline \multicolumn{9}{|l|}{ Knowledge of LP } \\
\hline Not understand & & 4 & & 18 & & 2.66 & 0.062 & $0.821-78$ \\
\hline Understand & & 15 & & 30 & & & & \\
\hline \multicolumn{9}{|l|}{ Benefit of LP } \\
\hline Not understand & & 11 & & 18 & & 0.97 & 0.99 & $0.31-3.15$ \\
\hline Understand & & 8 & & 13 & & & & \\
\hline \multicolumn{9}{|l|}{ Complication of LP } \\
\hline Not understand & & 4 & & 0 & & 3.1 & 0.01 & $2.02-4.64$ \\
\hline Understand & & 15 & & 31 & & & & \\
\hline \multicolumn{9}{|l|}{ Information of LP } \\
\hline Doctor & 14 & & 26 & 0.7 & 0.47 & & $0.13-2.1$ & \\
\hline Others & & 5 & & & 5 & & & \\
\hline
\end{tabular}

Father education was related to the refusal of LP procedure with PR 6.64 (95\%CI; $8.95-78.08, \mathrm{p}<$

\section{Discussion}

Based on the Regulation of the Minister of Health of the Republic of Indonesia No. 290/MENKES/PER/III/2008 on The Approval of medical procedures, all actions by doctors which will be imposed on patients have to obtain the approval either in written form or orally. The consent of medical procedure obtained by husbands, wives, biological parents, children, or their guardians after they get the explanation (Menkes, 2008).

In this study, 50 parents who were willing to be interviewed. This result shows the refusal rate is still high due knowledge; income, social environment, level of education, information from media, and health facility. The high level of education can affect attitude and decision. Level of education will give the good response to the information about the medical procedure. Whereas, refusal occurs about $38 \%$ of parents who have a low education (Table 4.2). A study in United Arab Emirates reported 87,5\% of parents did not know the benefit of the LP procedure after they get the explanation (Narchi H,2013). 
This study shows 45 parents $(90 \%)$ had understood about the procedure but 15 parents (33\%) refusal it. $42 \%$ parents understand the importance of LP as a diagnose and the acceleration of treatment to CNS infection. Parents refusal of LP due to concerns about the complications that will occur; a headache, pain in LP location, bleeding, infection, hernia, cardio-respiratory compromised, subarachnoid cyst, and leakage of cerebrospinal fluid. A study in Iran, reported 50 parents refuse of LP because fear about the complication (Khakshour et al., 2013) The result of this study also found that the difference in perception because there was the difference in the approach of explaining by doctors about the procedure and the benefit of LP. It could be seen in Table 4.3 which indicated that there were ten parents (20\%) who got information not from doctors but the others.

\section{REFERENCES}

[1] Doherty CM, Forbes R B. Diagnostic Lumbar Puncture. Ulster Med J. 2014;83(2):93102.

[2] Dzulfikar D. Tatalaksana Tekanan Tinggi Intrakranial pada Anak. Dalam Stabilization of the critically ill children. Penyunting Munar Lubis, Gema NY, Johan CS, Natasha Y, Indah NL, Ferry H, et al. USU Press. 2014. H.103-19.

[3] Ellenby MS, Tegtmeyer K, Lai S, Braner D A V. Lumbar Puncture. NEJM.2006; 355:e12.

[4] Evans Randolph W. Complications of lumbar puncture. Elsevier. 1998;83-01.

[5] Green WL. Health education was planning a diagnostic approach. The Johns Hopkins University. Mayfield Publishing Company. 2005.

[6] Kaushik JS, Narang M, Agarwal N. Informed Consent in pediatric practice. Indian Pediatr. 2010:1039-46.

[7] Khakshour Ali, Hashemi M, Tavakoli H, Sheikhi Z, Kiani MA, et.al. Evaluation of parental attitudes toward lumbar puncture in their children. Intern $\mathrm{J}$ Pediatr. 2013;1(2):19-3.

[8] Kneen R, Solomon T, Appleton R. The Role of Lumbar Puncture in Suspected CNS Infection - a Disappearing skill?. BMJ, 2016:181-83.

[9] L Catherine, Tacon, Flower O. Diagnosis and management of bacterial meningitis in the pediatric population: a review. EMI. 2012:1-8.

[10] Ling SG, Boey CCM. Lumbar puncture refusal in febrile convulsion. Singapore Med J. 2000;41(10):485-88.

[11] Malik AS. Consent for lumbar puncture factors that influence the decision. Malay J Paediatrics. 2000;1:35-1.

[12] Narchi H, Ghatasheh G, Hassani NA, Reyami LA, Khan Q. Comparison of underlying factors behind parental refusal or consent for lumbar puncture. World J Pediatr. 2013;9(4:336-41).

[13] Nigrovic LE, McQueen AA, Neuman MI. Lumbar puncture success rate is not influenced by family-member presence. Pediatrics. 2016;120(4):777-82.

[14] Notoatmodjo S. Pronosi kesehatan dan perilaku kesehatan. Rineka Cipta. Jakarta. 2012.

[15] Patel PB, Anderson HE, Keenly LD, Vinson DR. Informed consent documentation for lumbar puncture in the emergency department. West JEM. 2014;15(3):318-24.

[16] Peraturan Menteri Kesehatan Republik Indonesia tentang persetujuan tindakan kedokteran. 2008 [diakses tanggal 20 januari 2016]. Tersedia di 
http://www.idionline.org/wpcontent/uploads/2010/03/PMK-No.-290ttgPersetujuan-Tindakan-Kedokteran.

[17] Pokorn M. Pathogenesis and Classification of Central Nerv System Infection.eJFFC.2003;(5):1-4.

[18] Randel A. AAP Updates Guidelines for Evaluating Simple Febrile Seizures in Children. AAFP. 2011;83(11):1349-50.

[19] Riordan F, Cant AJ. When to do a lumbar puncture. BMJ. 2016:235-37.

[20] Risher. Sikap Manusia Teori dan Pengukurannya. Pustaka Pelajar. Yogyakarta. 2006.

[21] Saharso D, Siti NH. Infeksi susunan saraf pusat. Dalam Buku Ajar Neurologi Anak, penyunting Soetomenggolo T, Sofyan Ismael. Edisi ke-2. Jakarta: BP IDAI. 2009. h.339-52.

[22] Saifuddin A. Sikap Manusia Teori dan Pengukurannya. Edisi ke 2. Yogyakarta. Pustaka Pelajar. 1995.

[23] Sharif MR, Alizargar J, Sharif A. Rate of parental consent to lumbar puncture for diagnosis of febrile convulsion. Middle- East J Sci Res. 2014;21(3):427-30.

[24] William B. Pediatric lumbar puncture and cerebrospinal fluid analysis. Am J Emerg Med. 2013:1-10.

[25] Williams J, Umapathi T. Diagnostic lumbar puncture: minimizing complications. Intern Med J. 2008:587-91.

[26] Wlof MS, Patricia EM. Recognition and management of pediatric seizures. Pediatric Annals. 2006;35(5):1-12. 